$\mathrm{Nr} 6$

WARSZAWA-

KRAKÓw 2003

\author{
ARKADIUSZ STAŃCZYK
}

Uniwersytet Mikołaja Kopernika, Toruń

\title{
Społeczno-gospodarcze aspekty konkurencyjności Polski w warunkach globalizacji
}

Trzecia fala globalizacji jest pochodną postępu technicznego, standaryzacji procesów wytwarzania, wzrostu wydajności pracy, liberalizacji handlu i przepływu kapitału, upowszechniania się inwestycji zagranicznych oraz integracji regionalnej. Transformacja społeczno-gospodarcza rozpoczęta na początku lat 90 . minionego wieku wpłynęła na zmianę postrzegania naszego państwa przez międzynarodowe instytucje polityczne i gospodarcze, inwestorów oraz przywódców państwowych. W minionym dziesięcioleciu Polska stała się pełnoprawnym członkiem NATO, MFW, WTO oraz OECD. Przed nami rysuje się członkostwo w Unii Europejskiej. Efektem ponad 10-letniej transformacji są wyraźne zmiany społeczne i gospodarcze. Bilans tych zmian zawiera zarówno pozytywne, jak i negatywne zdarzenia.

Rozpoczynające się nowe stulecie sprzyja podsumowaniom oraz skłania do budowania planów na przyszłość. W ten nurt rozważań wpisuje się niniejsze opracowanie. Celem pracy jest przedstawienie miejsca Polski na tle wybranych krajów wysoko rozwiniętych skupionych w OECD (Organizacja Współpracy Gospodarczej i Rozwoju) oraz wskazanie głównych czynników wyznaczających pozycję konkurencyjną polskiej gospodarki i społeczeństwa na tle tych krajów.

W związku z tym, iż konkurencyjność traktowana jest wieloznacznie przez różnych autorów (część uważa, iż nie można mówić o konkurencyjności w odniesieniu do całej gospodarki), w niniejszej pracy przyjęto traktować konkurencyjność jako zdolność do rywalizacji, kooperacji i osiągania korzyści z otwartej gospodarki rynkowej przez całą gospodarkę narodową. Uszczegóławiając, pod pojęciem konkurencyjności kraju należy rozumieć zdolność do tworzenia w długim okresie coraz większego bogactwa w porównaniu $\mathrm{z}$ innymi krajami. Proces ten to skuteczne dostosowywanie się do zmieniających się warunków zewnętrznych, zrównoważony wzrost gospodarczy oraz zmniejszanie dystansu społeczno-eko-nomicznego i technologicznego względem bardziej rozwiniętych państw.

Zaznaczyć należy, iż głównym czynnikiem stymulującym konkurencyjność są reguły rządzące gospodarką rynkową, a władze państwowe traktuje się jako siły wspomagające i utrwalające konkurencyjność. 


\section{CHARAKTERYSTYKA OECD}

Historycznym początkiem działalności OECD była powojenna pomoc, jakiej po II wojnie światowej udzieliły Stany Zjednoczone Ameryki Północnej Europie w ramach tzw. Planu Marshalla ogłoszonego w 1947 roku. Rozdziałem wielomiliardowej pomocy zajęła się powołana w 1948 roku Europejska Organizacja Współpracy Gospodarczej (OEEC), która skupiała początkowo 16 państw: Austrię, Belgię, Danię, Francję, Niderlandy, Grecję, Irlandię, Islandię, Luksemburg, Norwegię, Portugalię, Szwecję, Szwajcarię, Turcję, Wielką Brytanię, Włochy oraz 3 strefy okupacyjne Niemiec. W 1949 roku Niemcy stały się 17 krajem członkowskim. W wyniku podziału Europy na dwa wrogie obozy polityczne i gospodarcze pomoc ta została odrzucona przez kraje socjalistyczne, podporządkowane wówczas ZSRR. W 1950 roku członkami stowarzyszonymi zostały Kanada i USA, a w 1959 roku Hiszpania. Jedynym krajem socjalistycznym współpracującym z tym ugrupowaniem gospodarczym była Jugosławia, która w 1951 roku była obserwatorem, a w 1959 roku członkiem stowarzyszonym. Zmiany, jakie zaszły w światowej gospodarce lat 50. wymusiły znalezienie nowej formuły współpracy tych krajów. Stąd w latach 1960-61 (na mocy konwencji podpisanej w Paryżu 14 grudnia 1960 r., która weszła w życie 30 września 1961 r.) w miejsce OEEC powołano do istnienia OECD (Organization for Economic Cooperation and Development) z siedzibą w Paryżu. Dwudziestkę krajów założycielskich (konwencji nie podpisała Jugosławia) w następnych latach uzupełniły kolejne kraje cechujące się dobrze rozwinięta, wolnorynkową gospodarka. W latach 60. skład OECD uzupełniły Japonia (1964) i Finlandia (1969), w 1. 70. Australia (1971) i Nowa Zelandia (1973). W latach 80. nie uzupełniano składu OECD. Dopiero zmiany lat 90. oraz spełnienie wysokich wymagań społeczno-gospodarczych pozwoliły na przyjęcie do grona OECD Meksyku (1994), Czech (1995), Węgier, Polski, Korei Południowej (1996) oraz Słowacji (2000).

Tabela 1. Podstawowe dane o społeczeństwie i gospodarce krajów OECD w 2001 roku

\begin{tabular}{|c|c|c|c|c|c|c|}
\hline \multirow[b]{2}{*}{ Wyszczególnienie } & \multirow[b]{2}{*}{ Jednostka } & \multirow[b]{2}{*}{ Świat } & \multirow[b]{2}{*}{ OECD } & Świat & OECD & \multirow{2}{*}{\begin{tabular}{|c|} 
OECD \\
udział \% \\
w świecie]
\end{tabular}} \\
\hline & & & & \multicolumn{2}{|c|}{ [na 100 mieszkańców] } & \\
\hline Powierzchnia & {$\left[\mathrm{mln} \mathrm{km}^{2}\right]$} & 135,6 & 34,8 & & & 25,7 \\
\hline Liczba ludności & [mln osób] & 6080 & 1137 & & & 18,7 \\
\hline PKB & [bln USD] & 31,5 & 25,2 & & & 81 \\
\hline PKB per capita & [USD/osobę] & 5180 & 22200 & & & \\
\hline $\begin{array}{l}\text { Przeciętny wiek dożycia } \\
(2000 \text { r.) }\end{array}$ & [lata] & 66,4 & 76,4 & & & \\
\hline $\begin{array}{l}\text { Śmiertelność niemowląt } \\
(2000 \text { r.) }\end{array}$ & $\begin{array}{l}\text { na } 1000 \\
\text { u.ż. }] \\
\end{array}$ & 56 & 13 & & & \\
\hline $\begin{array}{l}\text { Turyści zagraniczni (2000 } \\
\text { r.) }\end{array}$ & [mln osób] & 697,5 & 453,8 & 11,5 & 39,9 & 65 \\
\hline $\begin{array}{l}\text { Subskrybenci telefonii } \\
\text { komórkowej }\end{array}$ & [mln osób] & 1030 & 602,2 & 16,94 & 52,98 & 58,5 \\
\hline
\end{tabular}




\begin{tabular}{|l|l|r|r|r|r|r|}
\hline Komputery osobiste & [mln sztuk] & 550 & 393,8 & 9,05 & 34,6 & 71,6 \\
\hline $\begin{array}{l}\text { Standardowe linie } \\
\text { telefoniczne }\end{array}$ & [mln sztuk] & 1040 & 593,6 & 17,21 & 55,2 & 57,1 \\
\hline Użytkownicy Internetu & [osoby] & 505 & 385,2 & 8,5 & 33,9 & 76,3 \\
\hline $\begin{array}{l}\text { Wartość importu towarów } \\
\text { i usług }\end{array}$ & [mld USD] & 8140,0 & 5817,5 & $133900^{*}$ & $511700^{*}$ & 71,5 \\
\hline $\begin{array}{l}\text { Wartość eksportu towa- } \\
\text { rów i usług }\end{array}$ & [mld USD] & 7863,0 & 5620,0 & $129300^{*}$ & $494300^{*}$ & 71,5 \\
\hline Emisja CO 2 (2000 rok) & [mln ton] & 24947,9 & 12449,0 & $410^{* *}$ & $1095^{* *}$ & 49,9 \\
\hline Napływ BIZ & [mld USD] & 735,0 & 565,8 & $12089^{*}$ & $49763^{*}$ & 76,98 \\
\hline
\end{tabular}

*w USD na 100 mieszkańców

** w tonach na 100 mieszkańców

Źródło: Opracowanie własne na podstawie źródeł OECD, WTO, World Bank, UN, 2002

OECD in Figures 2001; Annual Report 2002 WTO; Human Development Report 2002; World Investment Report 2002

Najistotniejszym celem działalności OECD jest tworzenie i wprowadzanie w życie wspólnej polityki opartej na:

- wzroście gospodarczym,

- znoszeniu barier w handlu zagranicznym,

- wspieraniu reform rynkowych,

- koordynacji pomocy zagranicznej,

- wspieraniu inwestycji w krajach rozwijających się,

- stabilizacji finansowej.

Obecnie na OECD przypada 80\% światowego dochodu, przy czym ludność krajów członkowskich to jedynie $19 \%$ światowej populacji. Podstawowe informacje o społeczeństwie i gospodarce krajów OECD zawiera tabela 1.

\section{KONKURENCYJNOŚĆ MIĘDZYNARODOWA}

Przełom XX i XXI wieku zaznaczył się wyraźnym wzrostem konkurencyjności i nowoczesności gospodarek należących do grupy wiodących graczy światowego rynku. Polaryzacja na enklawy bogactwa rozrzucone pośród mas biednych społeczeństw uświadamia, jak trudno jest osiaggnąc gospodarczy sukces i jak długą drogę trzeba przebyć, aby osiagnąc cel, którym jest stabilność ekonomiczna kraju. Według Raportu o rozwoju społeczeństw

z 1999 roku na ok. 20\% ludności świata zamieszkujących najbogatsze kraje przypada 86\% światowego PKB, $82 \%$ wartości eksportu, $68 \%$ bezpośrednich inwestycji zagranicznych oraz $74 \%$ linii telefonicznych. Jednocześnie $20 \%$ najbiedniejszych dysponuje ok. $1 \%$ udziałem w każdej z wymienionych wcześniej dziedzin.

Odchodzenie społeczeństw od tradycyjnych gospodarek opartych na zasobach ziemi, pracy i kapitału ku gospodarkom opartym na wiedzy w jeszcze większym stopniu zintensyfikowało konkurencyjność. Odpowiedzialny uczestnik rozwiniętego rynku nie może sobie pozwolić na zastój czy chociażby okresową stagnację. Raczej planuje działania zmierzające do dynamizacji rozwoju. Ów rozwój oparty na kurczących się zasobach ograniczany jest 
poprzez splot czynników wewnętrznych (krajowych) i zewnętrznych (globalnych), które nie zawsze da się przewidzieć. Postęp gospodarczy i cywilizacyjny danego państwa wymaga określonych nakładów pracy i środków.

Główne czynniki konkurencyjności to m.in.: polityka gospodarcza państwa, system edukacyjny, etyka pracy, nowoczesna gospodarka, funkcjonowanie rynków kapitałowych, prawo gospodarcze, produktywność, koszty, technologie, eksportowe udziały rynkowe. Wielu spośród tych czynników nie można wyrazić za pomocą wskaźników ilościowych. Stąd też analiza konkurencyjności obejmuje interpretację wykraczającą poza porównanie tylko miar ilościowych.

\section{ZAŁOŻENIA BADAWCZE}

Dla porównania poziomu rozwoju społeczno-gospodarczego krajów OECD posłużono się miernikiem syntetycznym określającym dystans poszczególnych krajów w stosunku do kraju znajdującego się w najkorzystniejszej sytuacji z punktu widzenia danego miernika. Za najkorzystniejszy przyjmuje się miernik o najwyższej lub najniższej wartości w zależności od charakteru zmiennej. Dzieląc miernik dotyczący każdego kraju przez najkorzystniejszy - bądź na odwrót - otrzymuje się dystanse, jakie dzielą analizowany kraj od najlepszego w badanym okresie. Wartość miernika waha się od 0 do 1 . Dystanse liczone są dla wszystkich mierników cząstkowych, które z kolei służą do wyliczenia miernika syntetycznego będącego średnią $z$ dystansów cząstkowych.

$$
\begin{aligned}
& \mathbf{M}_{\mathbf{d}}=\mathbf{M}_{\mathbf{i}} / \mathbf{M}_{\mathbf{n k}} \quad \mathbf{l u b} \quad \mathbf{M}_{\mathbf{d}}=\mathbf{M}_{\mathbf{n k}} / \mathbf{M}_{\mathbf{i}} \\
& \mathbf{M}_{\mathbf{s d}}=\sum \mathbf{M}_{\mathbf{d}} / \mathbf{n} \\
& \mathbf{M}_{\mathrm{d}}-\text { miernik dystansów, } \\
& \mathbf{M}_{\mathrm{i}} \text { - miernik zmiennej dla i-tego kraju, } \\
& \mathbf{M}_{\mathrm{nk}}-\text { miernik najkorzystniejszy zmiennej, } \\
& \mathbf{M}_{\mathrm{sd}}-\text { syntetyczny miernik dystansu, } \\
& \mathrm{n} \text { - ilość zmiennych zastosowanych do porównań }
\end{aligned}
$$

Obliczone w ten sposób mierniki syntetyczne umożliwiają ustalenie kolejności krajów oraz odczytanie dystansów, jakie dzielą kraje. Odpowiedni dobór mierników wyjściowych pozwala na obiektywne uszeregowanie krajów. W badaniach uwzględniono zarówno mierniki społeczne, jak i gospodarcze. Tę drugą grupę tworzyły w większości mierniki technologiczne, wpływające obecnie w największym stopniu na konkurencyjność gospodarek poszczególnych krajów. Spośród 30 mierników cząstkowych 15 zakwalifikowano jako społeczne, a 15 jako technologiczno-gospodarcze. Następnie wyliczono syntetyczne mierniki dystansu dla grupy mierników charakteryzujących społeczeństwo oraz gospodarkę. W końcowej fazie wyliczono syntetyczny miernik dystansu dla obydwu grup.

Dane statystyczne pochodzą z publikowanych przez ONZ, Bank Światowy, OECD, MFW wydawnictw oraz raportów międzynarodowych instytucji np.: A.T. Kearney, World Economic Forum, Heritage Foundation itp. Wybierając dane kierowano się ich dostępnością oraz tym, aby dotyczyły roku 2000/2001. Niestety z powodu braku danych za te lata w 
kilku przypadkach posłużono się danymi za lata wcześniejsze. W badaniach uwzględniono 28 z 30 krajów członkowskich OECD. Z powodu braku danych statystycznych oraz specyfiki tych krajów (bardzo mała liczba ludności, charakterystyczna gospodarka) pominięto Islandię

i Luksemburg. Nie zmienia to jednak finalnego obrazu konkurencyjności w ramach OECD.

Tabela 2. Zestaw mierników wykorzystanych w badaniu

\begin{tabular}{|c|c|c|}
\hline Lp. & Mierniki społeczne & Mierniki technologiczno-gospodarcze \\
\hline 1. & Przeciętny wiek dożycia [lata] & PKB na mieszkańca wg PSN [USD/ per capita] \\
\hline 2. & $\begin{array}{l}\text { Śmiertelność niemowląt } \\
{[\text { [liczba zgonów na } 1000 \text { u. ż.] }}\end{array}$ & Udział usług w PKB [\%] \\
\hline 3. & $\begin{array}{l}\text { Urbanizacja [udział \% ludności miej- } \\
\text { skiej] }\end{array}$ & Wydatki na sferę B+R w PKB [\%] \\
\hline 4. & Liczba lekarzy na 1000 ludności & $\begin{array}{l}\text { Liczba kolorowych odbiorników TV } \\
\text { na } 100 \text { gospodarstw domowych }\end{array}$ \\
\hline 5. & $\begin{array}{l}\text { Wydatki na edukację w relacji } \\
\text { do PNB [\%] }\end{array}$ & $\begin{array}{l}\text { Subskrybenci telefonii komórkowej } \\
\text { na } 100 \text { mieszkańców }\end{array}$ \\
\hline 6. & $\begin{array}{l}\text { Wydatki na służbę zdrowia w relacji } \\
\text { do PKB [\%] }\end{array}$ & $\begin{array}{l}\text { Hosty internetowe } \\
\text { na } 1000 \text { mieszkańców }\end{array}$ \\
\hline 7. & $\begin{array}{l}\text { Udział pracujących w usługach do ogól- } \\
\text { nej liczby pracujących w gospodarce } \\
\text { narodowej [\%] }\end{array}$ & $\begin{array}{l}\text { Użytkownicy Internetu } \\
\text { na } 1000 \text { mieszkańców [\%] }\end{array}$ \\
\hline 8. & Stopa bezrobocia [\%] & Komputery osobiste na 100 mieszkańców \\
\hline 9. & $\begin{array}{l}\text { Liczba turystów zagranicznych } \\
\text { na } 100 \text { mieszkańców }\end{array}$ & $\begin{array}{l}\text { Liczba naukowców w sferze B+R na } 100000 \\
\text { mieszkańców }\end{array}$ \\
\hline 10. & Bezrobocie młodych [\%] & $\begin{array}{l}\text { Udział eksportu wyrobów High-Tech } \\
\text { w ogólnej wartości eksportu [\%] }\end{array}$ \\
\hline 11. & $\begin{array}{l}\text { Sprzedaż płyt kompaktowych z muzyką } \\
\text { [w USD/ mieszkańca] }\end{array}$ & Napływ BIZ w stosunku do PKB [\%] \\
\hline 12. & $\begin{array}{l}\text { Zachorowania na gruźlicę na } 100000 \\
\text { mieszkańców }\end{array}$ & Liczba studentów na 1000 mieszkańców \\
\hline 13. & Średni czas nauki $>15$. roku życia & Wymiana towarowa w relacji do PKB [\%] \\
\hline 14. & $\begin{array}{l}\text { Łóżka w szpitalach na } 1000 \text { mieszkań- } \\
\text { ców }\end{array}$ & Produktywność całkowita [PKB/ mieszkańca] \\
\hline 15. & Płodność kobiet [osoby] & $\begin{array}{l}\text { Koszt dostępu do Internetu w USD PSN } \\
\text { za } 40 \text { godz. użytkowania }\end{array}$ \\
\hline
\end{tabular}

Spośród mierników cząstkowych najbardziej dogodnym miernikiem tak pojętej konkurencyjności jest wielkość PKB w przeliczeniu na jednego mieszkańca, która jest syntetyczną miarą efektywności wykorzystania zasobów. Badanie czynników wpływających na kształtowanie się tego wskaźnika w długim okresie czasu pozwala na prognozowanie zmian względnej pozycji poszczególnych krajów na gospodarczej mapie świata, a także może stanowić podstawę do formułowania programów poprawy konkurencyjności gospodarki. Porównanie wartości PKB na mieszkańca w 2001 roku wg parytetu siły nabywczej ilustruje ryc. 1.

Dystans, jaki dzieli Polskę w stosunku do pozostałych rozwiniętych krajów OECD wskazuje, iż polityka państwa winna skupiać się na generowaniu bodźców stymulujących 
wzrost PKB. Dalsza liberalizacja musi współgrać $\mathrm{z}$ oczekiwaniami społeczeństwa uwzględniającymi ochronę interesu ogólnego.

W zależności od zewnętrznej i wewnętrznej sytuacji społeczno-gospodarczej rok osiągnięcia poziomu rozwoju krajów wysoko rozwiniętych w przypadku Polski szacowany jest na 2047 (scenariusz dotrzymywania kroku) lub 2028 (scenariusz nadrabiania dystansu). Najbardziej optymistyczne wizje mówią o roku 2019. Przy czym np. zaprzestanie reform instytucjonalnych, niekorzystna sytuacja w kraju lub na świecie, negatywne efekty globalizacji mogą zweryfikować owe scenariusze (Kołodko 2001).

ryc. 1 
W wyniku przeprowadzonej analizy uzyskano 3 zestawienia (rankingi) wskazujące na stopień konkurencyjności społeczeństw i gospodarek w ramach OECD.

Tabela 3. Ranking konkurencyjności krajów OECD.

Syntetyczny miernik dystansu dla krajów OECD w 2000 roku

\begin{tabular}{|c|c|c|c|c|c|c|c|c|}
\hline \multicolumn{3}{|c|}{$\begin{array}{c}\text { Ranking } \\
\text { konkurencyjności } \\
\text { społeczeństw }\end{array}$} & \multicolumn{3}{|c|}{$\begin{array}{c}\text { Ranking konkurencyjności } \\
\text { ekonomiczno- } \\
\text {-technologicznej }\end{array}$} & \multicolumn{3}{|c|}{$\begin{array}{l}\text { Ranking konkurencyjnosci } \\
\text { krajów OECD }\end{array}$} \\
\hline Miejsce & Kraj & Msd $_{\mathbf{s}}$ & Miejsce & Kraj & Msd $_{\text {et }}$ & Miejsce & Kraj & Msd $_{\text {set }}$ \\
\hline 1. & Norwegia & 0,76 & 1. & Szwecja & 0,78 & 1. & Norwegia & 0,73 \\
\hline 2. & Szwajcaria & 0,76 & 2. & Finlandia & $\mathbf{0 , 7 3}$ & 2. & Szwecja & 0,72 \\
\hline 3. & Austria & $\mathbf{0 , 7 0}$ & 3. & USA & $\mathbf{0 , 7 2}$ & 3. & Szwajcaria & 0,71 \\
\hline 4. & USA & 0,69 & 4. & Norwegia & 0,69 & 4. & USA & 0,705 \\
\hline 5. & Niderlandy & 0,69 & 5. & Niderlandy & 0,69 & 5. & Niderlandy & 0,69 \\
\hline 6. & Szwecja & 0,67 & 6. & Irlandia & 0,66 & 6. & Finlandia & 0,66 \\
\hline 7. & Dania & 0,66 & 7. & Szwajcaria & 0,66 & 7. & Dania & 0,65 \\
\hline 8. & $\begin{array}{l}\text { Nowa } \\
\text { Zelandia }\end{array}$ & 0,64 & 8. & Belgia & 0,65 & 8. & Irlandia & 0,65 \\
\hline 9. & Australia & 0,64 & 9. & Dania & 0,64 & 9. & Belgia & 0,63 \\
\hline 10. & Irlandia & 0,63 & 10. & Kanada & 0,60 & 10. & Austria & 0,62 \\
\hline 11. & Japonia & 0,63 & 11. & Japonia & 0,59 & 11. & Kanada & 0,61 \\
\hline 12. & Kanada & 0,63 & 12. & $\begin{array}{l}\text { Wielka } \\
\text { Brytania }\end{array}$ & $\mathbf{0 , 5 8}$ & 12. & Japonia & 0,61 \\
\hline 13. & Niemcy & 0,62 & 13. & Australia & 0,58 & 13. & Australia & 0,61 \\
\hline 14. & Francja & 0,62 & 14. & Niemcy & $\mathbf{0 , 5 7}$ & 14. & Niemcy & 0,59 \\
\hline 15. & Belgia & 0,62 & 15. & Francja & 0,56 & 15. & Francja & 0,59 \\
\hline 16. & $\begin{array}{l}\text { Wielka } \\
\text { Brytania }\end{array}$ & 0,60 & 16. & Austria & 0,55 & 16. & $\begin{array}{l}\text { Wielka } \\
\text { Brytania }\end{array}$ & 0,59 \\
\hline 17. & Finlandia & $\mathbf{0 , 5 8}$ & 17. & Korea Pd. & 0,54 & 17. & $\begin{array}{l}\text { Nowa } \\
\text { Zelandia }\end{array}$ & $\mathbf{0 , 5 8}$ \\
\hline 18. & Włochy & 0,55 & 18. & \begin{tabular}{|l|} 
Nowa \\
Zelandia \\
\end{tabular} & 0,52 & 18. & \begin{tabular}{|l|} 
Korea \\
Południowa \\
\end{tabular} & $\mathbf{0 , 5 3}$ \\
\hline 19. & Grecja & 0,54 & 19. & Włochy & 0,48 & 19. & Włochy & 0,51 \\
\hline 20. & Hiszpania & $\mathbf{0 , 5 3}$ & 20. & Hiszpania & $\mathbf{0 , 4 7}$ & 20. & Hiszpania & $\mathbf{0 , 5 0}$ \\
\hline 21. & Meksyk & $\mathbf{0 , 5 3}$ & 21. & Portugalia & 0,43 & 21. & Portugalia & $\mathbf{0 , 4 7}$ \\
\hline 22. & Węgry & $\mathbf{0 , 5 2}$ & 22. & Czechy & $\mathbf{0 , 4 1}$ & 22. & Czechy & 0,46 \\
\hline 23. & Korea Pd. & $\mathbf{0 , 5 1}$ & 23. & Węgry & $\mathbf{0 , 3 9}$ & 23. & Węgry & 0,46 \\
\hline 24. & Portugalia & $\mathbf{0 , 5 1}$ & 24. & Słowacja & $\mathbf{0 , 3 8}$ & 24. & Grecja & 0,45 \\
\hline 25. & Czechy & $\mathbf{0 , 5 1}$ & 25. & Grecja & $\mathbf{0 , 3 7}$ & 25. & Meksyk & $\mathbf{0 , 4 1}$ \\
\hline 26. & Polska & 0,44 & 26. & Meksyk & 0,29 & 26. & Słowacja & $\mathbf{0 , 4 1}$ \\
\hline 27. & Słowacja & $\mathbf{0 , 4 3}$ & 27. & Polska & 0,29 & 27. & Polska & 0,36 \\
\hline 28. & Turcja & 0,36 & 28. & Turcja & 0,23 & 28. & Turcja & $\mathbf{0 , 3 0}$ \\
\hline
\end{tabular}


Analizując dane cząstkowe i wyniki ostateczne można sformułować kilka wniosków i postulatów. Ich spełnienie warunkuje postęp i utrzymanie się Polski w gronie rozwiniętych krajów świata. Jako członkowie UE będziemy niejako zobligowani do postępu, a wewnętrzna konkurencyjność zmusi nas jako społeczeństwo do przewartościowania myślenia o stanie i perspektywach dalszego rozwoju.

- Największą konkurencyjnością społeczeństw i gospodarek (ich nowoczesność, technologizacja) charakteryzują się kraje skandynawskie.

- W przypadku niektórych krajów istnieją wyraźne dysproporcje w rozwoju społecznym i technologicznym.

- W Szwecji, Finlandii, USA, Irlandii, Belgii, Korei Pd. obserwuje się dysparytet pomiędzy konkurencyjnością technologiczną a społeczną.

- Szczególnie duże dysproporcje pomiędzy konkurencyjnością społeczną a technologiczną obserwuje się w Austrii, Meksyku, Polsce, Turcji, Grecji, Nowej Zelandii i na Węgrzech.

- Kraje OECD można podzielić na 4 grupy ze względu na konkurencyjność społeczeństw i gospodarek:

- Czechy i Węgry osiągnęły w wielu dziedzinach poziom najsłabiej rozwiniętych krajów UE (Grecji, Portugalii i Hiszpanii)

- Norwegia, Szwecja, Szwajcaria, USA, Niderlandy;

- Finlandia, Dania, Irlandia, Belgia, Austria, Kanada, Japonia, Australia, Niemcy, Francja, Wielka Brytania, Nowa Zelandia, Hiszpania;

- Korea Pd., Włochy, Hiszpania, Portugalia, Czechy, Węgry, Grecja;

- Meksyk, Słowacja, Polska, Turcja.

- Dystans dzielący Polskę od innych krajów jest szczególnie wyrazisty w przypadku konkurencyjności technologicznej.

- Znacznie mniejszy dystans dzieli Polskę w przypadku konkurencyjności społecznej.

- Do negatywnych zjawisk należy zaliczyć w przypadku Polski niskie nakłady na sferę $\mathrm{B}+\mathrm{R}$

- Pozytywnym zjawiskiem jest wydłużanie się przeciętnego dalszego trwania życia.

- Czynnikiem ograniczającym konkurencyjność i dynamikę wzrostu w Polsce jest niesprawność rynku pracy - wysoka stopa bezrobocia.

- Polskę charakteryzuje niski poziom technologizacji oraz infrastruktury technicznej, której rozwój utrudniony jest przez bardzo wysokie koszty dostępu do nowoczesności.

- Silną stroną są relatywnie niskie koszty pracy, chociaż w porównaniu z krajami Azji Południowej i Wschodniej są one 8-9-krotnie wyższe.

- Niski udział eksportu w PKB świadczy o niedostatecznym powiązaniu gospodarczym Polski z zagranicą oraz małą konkurencyjnością polskich wyrobów na rynku globalnym.

- Poprawa konkurencyjności Polski w stosunku do krajów OECD wymagać będzie dynamicznego wzrostu inwestycji oraz zmiany postrzegania naszej gospodarki nie tylko poprzez pryzmat niewydajnego rolnictwa i przestarzałego przemysłu. 


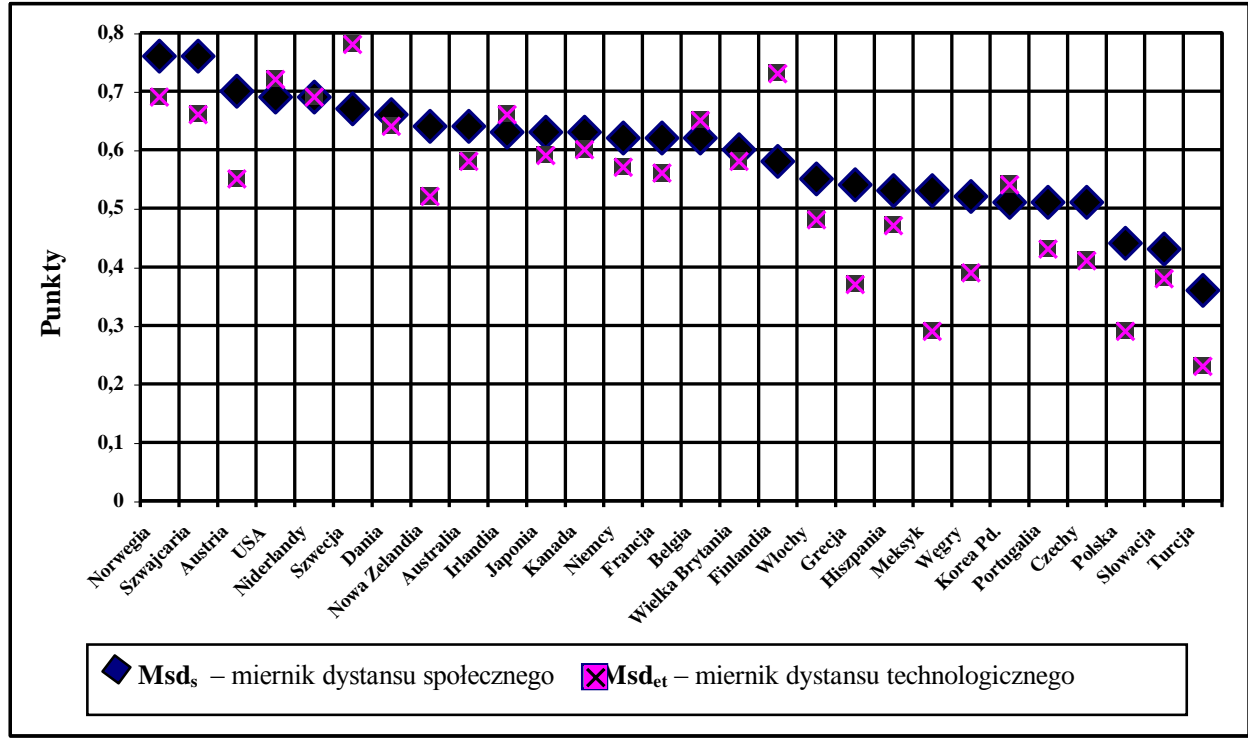

Ryc. 2. Porównanie rozwoju społeczeństw i gospodarek w krajach OECD na podstawie metody miernika dystansu

\section{INNOWACYJNOŚĆ POLSKIEJ GOSPODARKI NA TLE KRAJÓW OECD}

Miarą potencjału innowacyjnego gospodarki jest wielkość nakładów na sferę badawczo--rozwojową w stosunku do PKB. Jak wynika z dostępnych danych, wielkość tych nakładów obniżyła się z 1,5\% na początku lat 80 . do $0,9 \%$ na początku lat 90 . i $0,7 \%$ w 2000 r.

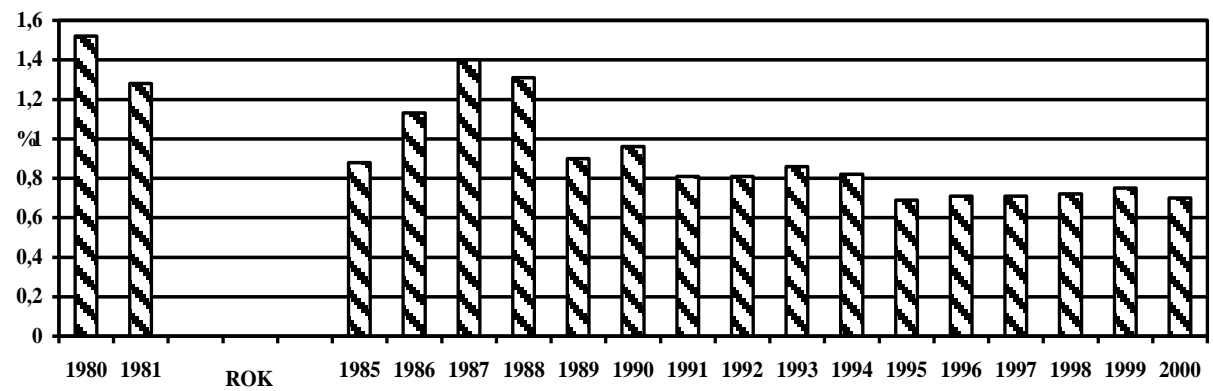

Ryc. 3. Nakłady na B+R w \% PKB w latach 1980-2000 w Polsce

Źródło: Rocznik Statystyczny, GUS, Warszawa 2000; B. Rejn, Nakłady na dziatalność badawczo-rozwojowq w Polsce, GUS, Warszawa 
Należy podkreślić, iż w krajach o silnie rozwiniętej gospodarce wielkość nakładów na sfere B+R przekracza 1,5\% PKB. W Niemczech osiaga wartość 2,29\%, we Francji 2,19\%, w Finlandii 2,89\%, w Szwecji 3,77\%, w Japonii 3,03\%, a w USA 2,58\%.

Spośród krajów transformujących gospodarkę wyższą wartość wskaźnika mają np. Czechy (1,29\%), Słowenia (1,42\%), a nawet Rosja (0,93\%). Przeciętny wskaźnik dla krajów Unii Europejskiej w 1999 roku wynosił 1,85\%.

Wielkość nakładów na sferę badawczo-rozwojową decydować będzie w przyszłości o konkurencyjności polskiej gospodarki na globalnym rynku. O naszych zapóźnieniach niech świadczy fakt, iż co najmniej 20 koncernów międzynarodowych wydaje więcej na ten cel niż Polska. Najwyższe nakłady przeznacza General Motors (blisko 9 mld USD w 1996 roku), następnie Ford Motor (6,8 mld), IBM (3,9 mld), Hewlett-Packard (2,7 mld) i Motorola (2,4 mld).

Tabela 4. Wydatki na sferę badawczo-rozwojową w wybranych krajach świata w 1999 r.

\begin{tabular}{|l|l|c|r|r|r|}
\hline \multirow{2}{*}{ Lp. } & \multicolumn{1}{|c|}{ Kraj } & \multicolumn{2}{|c|}{$\begin{array}{c}\text { Udział nakładów } \\
\text { na B+R w PKB [\%] }\end{array}$} & $\begin{array}{c}\text { Nakłady } \\
\text { na B+R } \\
\text { [mln USD] } \\
\text { PSN }^{*}\end{array}$ & $\begin{array}{c}\text { Nakłady } \\
\text { na B+R } \\
\text { per capita } \\
\text { [USD] }\end{array}$ \\
\cline { 3 - 4 } & $1990 \mathrm{r}$. & $1999 \mathrm{r}$. & 1,85 & 147711,7 & 394 \\
\hline 1. & Unia Europejska & 1,96 & 1,85 & 468 \\
\hline 2. & OECD & 2,30 & 2,21 & 519482,9 & 422 \\
\hline 3. & Austria & 1,39 & 1,8 & 3414,2 & 162 \\
\hline 4. & Czechy & 2,02 & 1,29 & 1665,0 & 722 \\
\hline 5. & Finlandia & 1,88 & 3,19 & 3732,2 & 480 \\
\hline 6. & Francja & 2,37 & 2,17 & 28415,3 & 155 \\
\hline 7. & Hiszpania & 0,81 & 0,89 & 6115,6 & 597 \\
\hline 8. & Islandia & 0,98 & 2,32 & 166,1 & 710 \\
\hline 9. & Japonia & 2,85 & 3,04 & 90003,4 & 420 \\
\hline 10. & Kanada & 1,54 & 1,66 & 12815,0 & 373 \\
\hline 11. & Korea & 1,92 & 2,46 & 17496,9 & 31 \\
\hline 12. & Meksyk & 0,22 & 0,40 & 3041,8 & 549 \\
\hline 13. & Niemcy & 2,75 & 2,44 & 45083,4 & 449 \\
\hline 14. & Norwegia & 1,69 & 1,70 & 2001,8 & 65 \\
\hline 15. & Polska & 0,96 & 0,75 & 2496,7 & 120 \\
\hline 16. & Portugalia & 0,51 & 0,77 & 1202,1 & 69 \\
\hline 17. & Słowacja & 1,75 & 0,68 & 374,0 & 840 \\
\hline 18. & Szwecja & 2,84 & 3,8 & 7448,4 & 73 \\
\hline 19. & USA & 2,65 & 2,64 & 226428,2 & 383 \\
\hline 20. & Węgry & 1,46 & 0,68 & 735,3 & \\
\hline 21. & Wielka Brytania & 2,16 & 1,87 & 22759,2 & \\
\hline
\end{tabular}

Źródło: Obliczenia własne na podstawie Main Science and Technology Indicators, OECD, 2001

Tak duże dysproporcje pomiędzy Polską a krajami członkowskimi UE oraz OECD, przy niewielkich nakładach z naszej strony, pozwalają na stwierdzenie, iż grozi nam zapaść cywilizacyjna w zakresie innowacyjności gospodarki. Potwierdzają to chociażby badania niezależnych instytucji (World Economic Forum), które przygotowują Ranking konkurencyjności (Global Competitiveness Report 2002), wg którego Polska zajmuje wśród 75 badanych krajów miejsce 41. Spośród krajów transformujących gospodarkę wyżej od nas

* PSN - parytet siły nabywczej pieniądza. 
są Czechy (37. miejsce), Węgry (28), Słowenia (31), Estonia (29), Słowacja (40). Niestety Polska w porównaniu z 2000 rokiem spadła z 34. miejsca. Ci sami eksperci oceniali także innowacyjność Polski, opierając się m.in. na liczbie patentów i wynalazków. Wg ich badań Polska plasuje się na 39. miejscu na 60 analizowanych państw.

ryc. 4 
Podobne badania przeprowadziła międzynarodowa instytucja IMD. Według jej badań na 49 państw Polska w 2002 roku zajmowała 45. miejsce pod względem konkurencyjności. W tych badaniach uwzględniono blisko 300 wskaźników pogrupowanych w 8 kategorii: wewnętrzna siła gospodarcza, umiędzynarodowienie gospodarki, działalność rządu, sektor finansowy, infrastruktura, zarządzanie, zasoby pracy. Najmniej konkurencyjni jesteśmy pod względem rozwoju infrastruktury, gdyż zajmujemy przedostatnie miejsce. Najwyższe miejsce zajmujemy w wynikach gospodarczych -42 .

Badania międzynarodowych instytucji wskazują na duże zapóźnienia pod względem technologicznego rozwoju. Konkurowanie z innymi krajami w dobie powszechnej technicyzacji gospodarki powoduje, iż trzeba wspólnego wysiłku, nie tylko państwa, ale i prywatnych inwestorów (głównie koncernów przemysłowych).

Struktura nakładów na B+R w Polsce wskazuje, iż główny ciężar postępu w kraju spoczywa na barkach biednego państwa. W niewielkim stopniu przemysł współfinansuje postęp naukowy i technologiczny. W przypadku krajów wysoko rozwiniętych to głównie wielkie firmy uczestniczą w podnoszeniu konkurencyjności technologicznej państwa.

Efektem niewystarczających nakładów na szeroko rozumiane innowacje w gospodarce jest niski udział eksportu wyrobów high i medium technology w stosunku do wartości eksportu towarów. Dla Polski wielkość ta w 1999 r. osiagnęła 36,2\%, gdy w większości krajów wysoko rozwiniętych gospodarczo przekraczała $50 \%$, a niejednokrotnie $60 \%$, np.: dla Japonii 81\%, USA 66\%, Korei Pd. 67\%, Wielkiej Brytanii 62\%, Singapuru 75\%.

Współczesną miarą dyfuzji innowacji jest bez wątpienia dostępność społeczeństwa do Internetu. Stosując wskaźnik podłączonych komputerów do Internetu na 1000 ludności można określić, w jakim stopniu społeczeństwo jest otwarte i podatne na zmiany technologiczne. W Polsce w 2000 r. wielkość tego wskaźnika wynosiła 11,4 hostów/1000 ludności, w Finlandii 200, Norwegii 194, USA 180, Szwecji 126, Japonii 49, Czechach 25, na Węgrzech 22, a w Estonii 43 hosty/1000 mieszkańców.

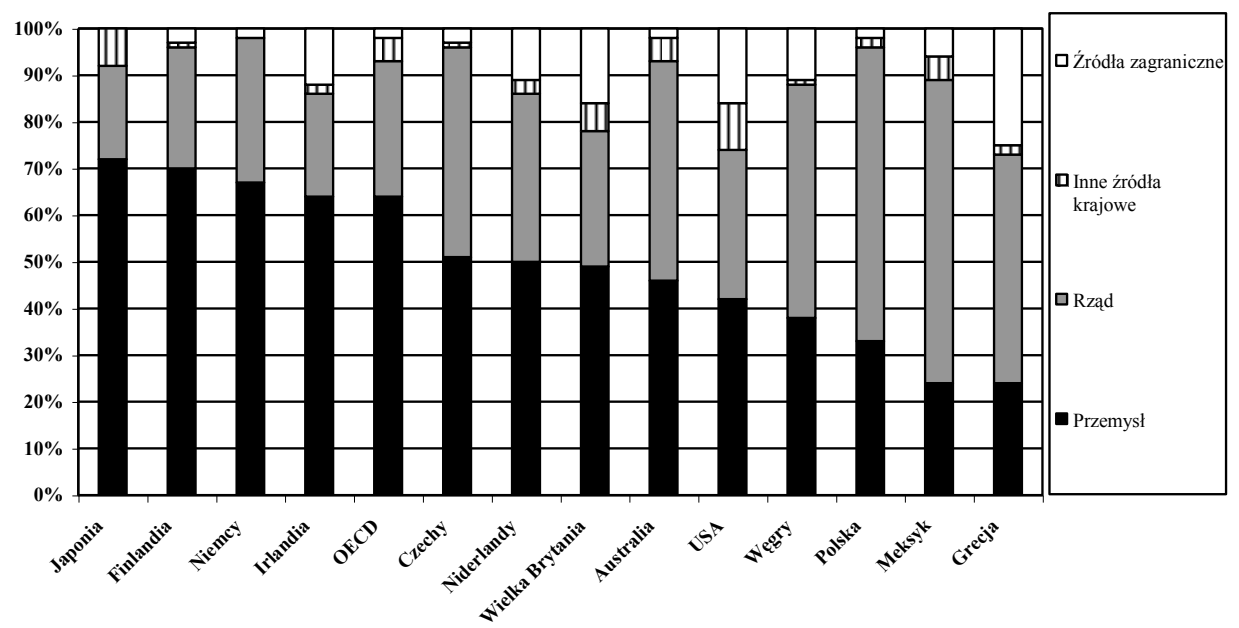

Ryc. 5. Struktura finansowania sfery B+R w $2001 \mathrm{r}$. w wybranych krajach OECD

Źródło: OECD, MSTI Database, June 2002 


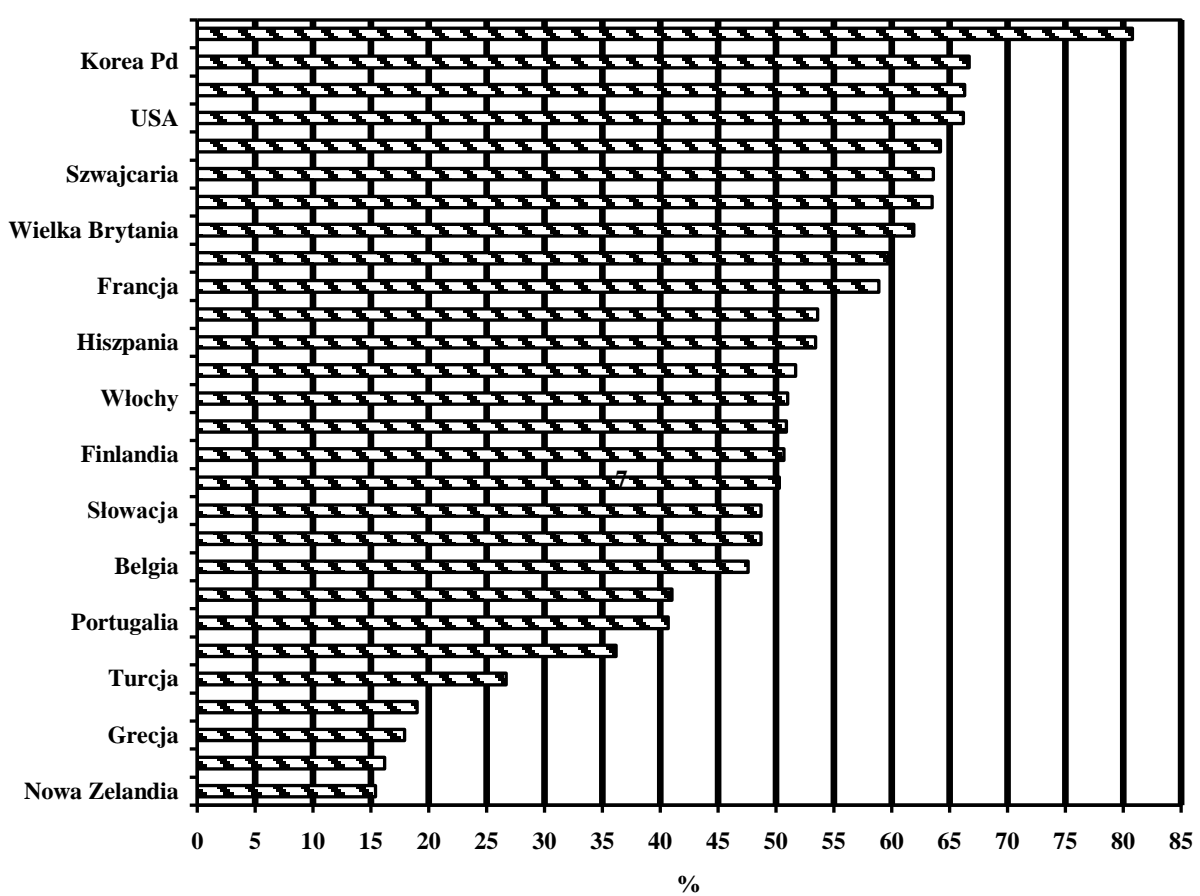

Ryc. 6. Udział eksportu wysokich i średnich technologii w wartości eksportu wyrobów przemysłowych w krajach OECD w 2000 roku Źródło: OECD In Figures, OECD, Paris 2001

Niska efektywność dyfuzji wynika z coraz mniejszej aktywności polskich wynalazców w realizacji patentów. Niewielkie nakłady zahamowały w znacznym stopniu innowacyjność polskich naukowców i inżynierów. W latach 90. zanotowano spadek o 40\% zgłaszanych wynalazków oraz o $70 \%$ udzielonych patentów krajowych, przy jednoczesnym wzroście o $270 \%$ wynalazków i udzielonych patentów zagranicznych (tabela 5). Duże potrzeby technologiczne polskiej gospodarki z powodu niskiej innowacyjności krajowej muszą być kompensowane wynalazczością pochodzącą z zagranicy. Nowa myśl techniczna dociera do Polski najczęściej wraz z inwestycjami kapitałowymi w rodzimy przemysł.

Tabela 5. Wynalazki i wzory użytkowe krajowe i zagraniczne w Polsce

\begin{tabular}{|l|l|l|l|l|l|l|l|l|l|l|l|l|l|}
\hline Wyszczególnienie & 1990 & 1991 & 1992 & 1993 & 1994 & 1995 & 1996 & 1997 & 1998 & 1999 & 2000 \\
\hline \multicolumn{10}{|c|}{ KRAJOWE } \\
\multicolumn{10}{|c|}{ Wynalazki } \\
\hline Zgłoszone & 4105 & 3389 & 2896 & 2658 & 2676 & 2595 & 2411 & 2399 & 2407 & 2285 & 2404 \\
\hline Udzielone patenty & 3242 & 3418 & 3443 & 2461 & 1825 & 1619 & 1405 & 1179 & 1174 & 1022 & 939 \\
\hline \multicolumn{10}{|c|}{ Wzory użytkowe } \\
\hline Zgłoszone & 2578 & 2451 & 2621 & 2550 & 2387 & 2119 & 1800 & 1589 & 1525 & 1290 & 1274 \\
\hline \multicolumn{10}{|c|}{ ZAGRANICZNE wynalazki zgłoszone w Polsce } \\
\hline Zgłoszone & 1316 & 1089 & 1349 & 1807 & 2221 & 2879 & 3262 & 3948 & 4128 & 4671 & 4894 \\
\hline Udzielone patenty & 405 & 371 & 409 & 480 & 735 & 989 & 1160 & 1151 & 1242 & 1214 & 1524 \\
\hline
\end{tabular}

Źródło: Dane statystyczne GUS 
Z przeprowadzonej analizy wynika, iż nie możemy jako państwo i społeczeństwo dopuścić do dalszej zapaści w dziedzinie innowacyjności. Dlatego niezbędne wydaje się podjęcie szerokich działań zmierzających do bardziej racjonalnego dysponowania środkami publicznymi oraz pozyskiwania środków z przedsiębiorstw krajowych i z zagranicy przeznaczonych na sferę innowacyjną. $Z$ bogatego zestawu narzędzi polityki innowacyjnej można by w najbliższym czasie wykorzystać narzędzia finansowo-kredytowe, podatkowe, oświatowe, polityczne oraz informacyjne. Odkładanie tych działań na tzw. lepsze czasy spowoduje wyraźną zapaść cywilizacyjną, z której będzie nam bardzo trudno się wydobyć.

Fakt, że prawie wszystkie kraje (z wyjątkiem Turcji) OECD notowane są znacznie wyżej pod względem konkurencyjności niż Polska, pozwala na rozpoznanie podstawowych przyczyn i skali zapóźnień polskiej gospodarki. Ponadto analizą porównawczą objęte zostały Węgry, Czechy i Słowacja, które zbliżone są do Polski tak pod względem stopnia zaawansowania transformacji gospodarczej, jak i poziomu rozwoju gospodarczego. Uwzględnienie tych krajów w analizie pozwala na uwypuklenie specyficznych uwarunkowań polskiej gospodarki oraz na wskazanie różnic w dynamice dostosowań zachodzących w tych krajach. Śledzenie zmian w kształtowaniu się czynników wpływających na konkurencyjność tych krajów ma znaczenie ze względu na ich wpływ na ocenę atrakcyjności inwestycyjnej Polski. Tego typu analiza porównawcza pozwala na określenie priorytetów polityki gospodarczej zmierzającej do wyrównania różnic w poziomie konkurencyjności w stosunku do krajów wyżej rozwiniętych pod względem gospodarczym.

\section{Literatura}

Kołodko G.W., 2001, Globalizacja a perspektywy rozwoju krajów posocjalistycznych, Toruń Stańczyk A., 2002, Innowacyjność polskiej gospodarki w warunkach globalizacji, [w:] Geograficzne uwarunkowania rozwoju Małopolski, Kraków

Strategia rozwoju Polski do roku 2020, 2000, t. 1, Warszawa

Struktury przemystowe w gospodarce, 1997, pod. red. L. Olszewskiego i J. Mozrzymasa, Wrocław

Współczesna gospodarka świata, 1999, pod red. A.B. Kisiel-Łowczyc, Gdańsk

Wysokińska Z., 2001, Konkurencyjność w międzynarodowym i globalnym handlu technologiami, Warszawa-Lódź 